\title{
Project-based Learning: Connotation, Characteristics and Misunderstandings
}

Peigeng Guo

Jiangxi Normal University, Nanchang, Jiangxi, China

\begin{abstract}
As a kind of teaching mode, project-based learning starts from the driving problems in the real world, aiming to solve learning problems, improve students' innovation ability and practical ability, as well as promote students' deep learning. It makes a vital difference in solving the current difficulties in reading teaching, which is characterized by process, authenticity and development. Due to the reading teaching is still in exploration stage from the perspective of project-based learning, there are inevitable problems in the actual teaching process, including improper time arrangement and lack of planning. Besides, learning is a mere formality, lacking effectiveness. So teachers need to be more careful to improve the teaching quality and efficiency of project-based learning.
\end{abstract}

Key words: teaching reform; reading teaching; project-based learning; strengthen moral education and cultivate people

\section{Introduction}

With the continuous advancement of the new curriculum reform, teaching begins to train students' innovative and practical ability. As an important part of Chinese teaching, reading teaching also bears the important mission of discipline education. However, in terms of the present situation of reading teaching in our country, there are still many problems that need to be solved urgently such as superficial teaching and rote memorization. And project-based learning is an effective teaching model to solve these problems. The newly issued Chinese Curriculum Standards for Ordinary Senior High Schools (2017 Edition) emphasized that "Chinese learning task group takes learning projects as the carrier", which shows the importance of project-based learning for Chinese teaching. The purpose of project-based learning is no longer to master knowledge, but through solving learning problems to improve students' innovative and practical ability and to promote students' deep learning. This paper tries to make a simple explanation of the connotation and characteristics of projectbased learning and its misunderstandings.

\section{The Connotation of Project-based Learning}

Project-based learning (PBL), originated in the USA in the 20th century, is a teaching mode from John Dewey's pragmatism teaching thought. In 1918, Kerberch firstly put forward the concept of project-based learning. He believed that every kind of behavior that students apparently intend to do can be called a project. Buck Educational Research Institute in America has long been committed to the research of PBL (Project-based Learning). They believed that it is a set of systematic teaching methods and a process of exploring complex or real problems and elaborating, planning and implementing the design of project works. With the advancement of foreign scholars' research on it, China has also introduced project-based learning. Liu Jingfu and Zhong Zhixian believed that project-based learning is a new type of

Copyright (C) 2021 by author(s) and Frontier Scientific Research Publishing Inc.

This work is licensed under the Creative Commons Attribution International License (CC BY 4.0).

http://creativecommons.org/licenses/by/4.0/ 
inquiry learning mode, which centers on the concept and principle of discipline, aiming at making works and selling them to customers with the help of various resources in the real world within a certain period of time. The author agrees with the views of Zhong Zhixian and interprets project-based learning as an efficient teaching model. However, it should be a teaching model based on Chinese curriculum standards and students' actual situation. And it starts from the driving problems in the real world, aiming at improving students' innovation ability and practical ability and promoting students' deep learning by solving learning problems.

\section{The Characteristics of Project-based Learning}

After more than 20 years of new curriculum reform, Chinese teaching in China has achieved fruitful results. However, after a careful review of the current situation of reading teaching in China, it is found that problems such as rote memorization in superficial teaching are still very common. Project learning is a bold attempt to solve the current difficulties in reading teaching. It shoulders the important mission of subject education and has the characteristics of process, authenticity and development.

\subsection{Characteristics of process}

Process refers to the participation of the learning subject in the whole learning process. Project-based learning emphasizes students' personal experience and a high involvement in the whole process, not simply taste it, let alone watching it from the side. The process of project-based learning is mainly reflected in the following two aspects: first, all students participate in the whole teaching activities. Second, students take part in all teaching process, including clarifying learning theme, setting learning objectives, designing driving tasks, displaying learning achievements, and carrying out evaluation activities.

\subsection{Authenticity}

In the traditional reading teaching, teachers often regard the Chinese book as the only teaching resources, but do not pay attention to the students' real life to carry out the teaching materials for the second time. The Chinese book is merely the main teaching content, but the teaching content also includes the teachers' processing of the book. In addition, the teaching place of traditional reading teaching is only limited to the classroom, which hinders the transformation of students' knowledge to ability and ignores the connection between Chinese course and students' real life. While projectbased learning is generally based on students' real life. Learners face real and specific problems, and such problems can better stimulate students' inner motivation.

\subsection{Development}

"For the development of every student" is the pursuing value of reading teaching. Project-based learning is also a kind of developmental teaching. It no longer pays much attention to students' academic performance, but is devoted to promoting students' future development in real practical activities. As Li Xueshu said, once our teaching regards knowledge, ability and scores as the fundamental pursuit, education will become the source of pain in students' lives. In fact, it also reflects the center shifting from knowledge to student and ability.

Project-based learning is a task-driven teaching mode based on learning themes. With the purpose of students development, it realizes the solution of problems and the construction of meaning through a series of real activities, emphasizes the participation of students in the process of carrying out activities, which is a kind of process teaching. At the same time, it emphasizes the truth-driven nature of learning tasks and is a kind of truth-driven teaching.

\section{The Misunderstandings of Project-based Learning}

As a teaching mode, project-based learning, combining with reading teaching, can effectively improve students' innovative and practical abilities and promote students' deep learning. However, the research on reading teaching under the 
project-based learning perspective is not mature enough, so there are inevitable some teaching misunderstandings in the practical process.

\subsection{Improper time arrangement}

The development of PBL includes some learning activities, such as defining learning topics and formulating learning goals. This series of links requires teachers and students to spend much time on it. About reading teaching, students need to read more books before class to ensure the process of project-based learning smoothly. However, due to the negative influence of exam-oriented education, teachers and students have to find ways to study the content of the exam. In order to improve students' academic performance, teachers spend much time explaining textbook knowledge, so there is no extra time to carry out project-based learning. As a result, there are problems such as unreasonable time arrangements and inability to make reasonable planning arrangements based on specific tasks and problems. In order to give full play to the advantages of PBL in reading teaching, Chinese teachers should plan their time reasonably and spend part of their time on project-based learning in order to cultivate students' innovative and practical abilities.

\subsection{Lack of planning}

In PBL, the learning task has a certain degree of difficulty and is not easy to complete within the limited time if we merely depend on the the power of the students. Therefore, it is necessary to adopt teamwork. However, some teachers believe that project-based learning means that students make products by themselves under the guidance of teachers, which is the complete implementation of project-based learning. The consequence is that in the process of project-based learning, teachers only require students to complete tasks instead of focusing on cooperation and communication among students. Project-based learning also integrates the learning context, content, methods, and resources to form a unique learning carrier or realization approach. Its purpose is to enable students to actively explore solutions to problems in practical situations. Therefore, teachers should seize the opportunity and efficiently use the time, so that students can realize the transformation and application of knowledge in hands-on practice to solve some practical problems.

\section{Conclusions}

We introduced PBL into reading teaching, which ensure students' dominant position in reading and give full play to the value of reading teaching. Regrettably, there are some teaching errors in reading teaching from the perspective of project-based learning. Therefore, when carrying out project-based learning, teachers should deeply understand the connotation of project-based learning and grasp its essential characteristics, so as to carry out reading teaching in a scientific and reasonable way. Only in this way can teachers realize the objective of discipline education and fulfill the fundamental task of cultivating people by virtue.

\section{Conflicts of Interest}

The author declares no conflicts of interest regarding the publication of this paper.

\section{Acknowledgments}

This paper is periodic achievement of the research on junior middle school Chinese reading strategies based on indepth teaching supported by Jiangxi Province 2020 Graduate Innovation Fund (Project No. :YC2020 S218).

\section{References}

[1] Chen J.R. (2017). Tao Xingzhi and Kerberch. Journal of Hebei Normal University (Education Science Edition), (1): 33-38

[2] Buck Educational Research Institute. (2008). Project-based Learning Teacher's Guide-21st Century Middle School Pedagogy (2nd edition). Education Press, Beijing.

[3] Liu J.F and Zhong Z.X. (2002). Research on Project-based Learning (PBL) Model. Foreign Education Research, 
(11): 18-22.

[4] Liu Y.S. (2002). Project Learning---An Important Learning Method in the Information age. Chinese Journal of Education, (1): 36-38.

[5] Li X.S. (2008). Vision of "Effective Teaching". Global Education Outlook, (11): 28-31.

[6] Liu Y.D. (2010). Research on Project Learning in My Country: Problems and Trends. Journal of Suzhou University (Philosophy and Social Sciences Edition), (4): 182-187. 